\title{
Determinants of infectious disease in children: Epidemiological Phenomena
}

\author{
Yarmaliza $^{1 a^{*}}$, Teungku Nih Farisni ${ }^{2 b}$, Fitriani $^{3 c}$, Zakiyuddin $^{4 d}$, Fitrah Reynaldi $^{5 e}$, Lili Eky Nursia N$^{6 f}$ \\ 1,2,3,4,5,6 Public Health Faculty, Teuku Umar University \\ E-mail: yarmaliza@gmail.com
}

\begin{abstract}
Diarrhea is a disease with changes in the shape and concentration of feces, which softens until melted, and increases the frequency of bowel movements more than normal ( 3 times or more a day). Data from Tanoh Manyang Village in 2014 showed the proportion of diar-rhea in infants was $12 \%$ of 144 children, in $201526 \%$ of 156 children, in 2016 as many as $40 \%$ of 343 children. The purpose of this study was to determine the effect of maternal culture on the incidence of infectious diseases (diarrhea) in infants. The population in this study 138, with sampling using total sampilng. This type of analytic survey research with cross sectional approach, data analysis using univariate, bivariate, and multivariate. Chi-square test results showed that mothers 'knowledge and attitudes as well as clean and healthy life behaviors of mothers affected the incidence of diarrhea in infants $(p<0.05)$, while the results of multivariate logistic regression tests showed that mothers' clean and healthy life behavior had a stronger influence on incidence of diarrhea in toddlers with Exp (B) value of 38, 201. Conclusions from the results of multivariate regression tests the mother's clean and healthy behavior has a strong influence on the incidence of diarrhea in infants. It is suggested that related agencies can increase health promotion in the form of counseling to the community so as to increase knowledge of clean and healthy living behavior in preventing infectious diseases, especially the incidence of diarrhea in infants.
\end{abstract}

Keywords: Knowledge, Attitude, Clean and Healthy Living Behavior

\section{INTRODUCTION}

Children are assets of the future that will continue development in the future for the country. The fastest development period in a child's life occurs in infancy. Circumstances that are considered necessary to watch out for attacking children are the occurrence of health problems or diseases, one example of health problems that occur in toddlers is the incidence of diarrhea. The incidence of diarrhea is still a major cause of morbidity and death in humans. Almost all age groups and all geographical regions of the world are attacked by diarrhea, but high mortality rates are found in infants and toddlers.

The magnitude of the problem can be seen from the high morbidity and mortality rate due to diarrhea, if this is not resolved immediately it will cause dehydration and can result in death. The World Health Organization (WHO) estimates that 4 billion cases occurred in the world in 2000 and 2.2 million of them died, mostly children under 5 years of age, then the latest data obtained from the Ministry of Health shows that diarrhea is a killer disease. 2 babies under 5 years old (toddlers) in Indonesia after pneumonia or pneumonia.

Diarrhea is one of the main causes of infant mortality in developing countries. The incidence of diarrhea in children every year is estimated at 2 billion, and more than half are found in Africa and South Asia and the consequences of this disease are more severe and dead-ly. Globally every year this disease causes under five deaths of 1.6 million. The number of diarrhea cases in Indonesia in 2012 was 1,654, and 34 people died because of this diarrhea. In 2013 the number of cases of diarrhea was 646 cases with 7 people dead (Ministry of Health Republic of Indonesia, 2013). The number of cases of diarrhea

\footnotetext{
*Corresponding Author :

Yarmaliza

Program Studi Ilmu Kesehatan Masyarakat

Universitas Teuku Umar, Indonesia

Email : yarmaliza@gmail.com
} 
in Indonesia in 2014 is estimated at $8,713,537$ cases. While the number of diarrhea cases handled was $8,490,976$ cases. The number of cases of diarrhea in Indonesia in 2015 is estimated at $5,405,235$ cases. While the number of diarrhea cases handled was 4,017,861 cases (Ministry of Health Republic of indonesia, 2015). The underfive mortality rate due to diarrhea in Aceh province in 2011 was $62 / 1000$ live births, in 2012 it decreased to $52 / 1000$ live births, in 2013 it decreased again to $48 / 1000$ live births. Although the incidence of diarrhea has decreased, underfive deaths due to diarrhea need to be watched out for, because the incidence of diarrhea has the potential to cause outbreaks (extraordinary events).

Based on medical record data from the Teunom Community Health Center in 2013 there were 1,157 toddlers, while 279 (24\%) toddlers had diarrhea. In 2014 there were 1,156 toddlers with 166 (14\%) toddlers with diarrhea. In 2015 there were 1,248 toddlers and number of toddlers with diarrhea were 215 (17\%) toddlers. In 2016 in the working area of the Teunom puskesmas there were 2,548 tod-dlers, of which 343 (13\%) toddlers experienced diarrhea (Community Health Center, 2016).

One of the risk factors for diarrhea in infants is due to a lack of understanding or attitude of the mother about personal hygiene, both concerning the cleanliness of mothers and toddlers and the cleanliness of the environment around the household. Risk factors for padea diarrhea in addition to intrinsic and extrinsic factors are also strongly influenced by the behavior of mothers or caregivers because toddlers are still unable to take care of themselves and are very dependent on their environment, so if mothers of toddlers or

\section{MATERIAL AND METHODS}

This type of research is analytical survey and research design with Cross Sectional approach, where the independent and bound variables are examined at the same time when the study is conducted (Budiarto, 2012), which aims to determine the effect of cultural characteristics of mother's culture (knowledge, attitudes and be-

\section{*Corresponding Author :}

Yarmaliza

Program Studi Ilmu Kesehatan Masyarakat

Universitas Teuku Umar, Indonesia

Email : yarmaliza@gmail.com toddlers caregivers cannot care for toddlers properly and healthy then the incidence of diarrhea in infants cannot be avoided.

In general, risk factors for diarrhea are environmental factors (the availability of clean water, family latrines, garbage disposal, waste water disposal, animal waste due to the distance of the cage close to the settlement), clean and healthy living behavior, immunity, digestive tract infections, allergies, malabsorption and poisoning.

Based on observations of researchers in the District of Teunom, where this District is one of the Districts that often experience flooding during heavy rains. This greatly affects the health of the surrounding community, where flooding can cause various diseases one of which is diarrhea. This is also based on observations of environmental researchers living mothers whose babies have diarrhea. Researchers see that there is garbage piled around the mother's house, this causes a lot of flies there. This situation is very dangerous for health, especially for toddlers, where flies will land on food and can cause diarrhea. Furthermore, based on the results of interviews with 8 mothers who have toddlers who experience diarrhea, this is due to mothers not knowing the cause of toddlers experiencing diarrhea, and the attitude of mothers who are less attentive to their toddlers. All this can be seen from the unclean behavior of mothers where mothers do not accustom their toddlers to washing their hands before eating, mothers also do not pay attention to the cleanliness of food eaten by children, such as food not covered on the table.

haviors of clean living and healthy mothers to the incidence of toddler diarrhea in Tanoh Manyang Village, Teunom District, Aceh Jaya District Data analysis using uinvariate, bivariate and multivariate popu-lation The population in this study were all mothers who had toddlers affected by diarrhea in Tanoh Manyang Village, Teunom District, 
Aceh Jaya District. 138 people with a sampling procedure using total sampling, that is, all mothers (138 mothers) who have toddlers affected by

\section{RESULTS AND DISCUSSION}

Based on Table. 1 shows that the mother's knowledge is good with a percentage that is $60.1 \%$, while the mother's knowledge that is not good shows the percentage $(39.9 \%)$. Likewise, the attitude of the mother, from the Table. 1 we diarrhea in Tanoh Manyang Village, Teunom District, Aceh Jaya Regency.

can see that mothers who have a positive attitude with a percentage of $50.74 \%$., While those who have a negative attitude show a percentage (49.3\%). In Table 1 it can also be seen that women who have good clean healthy behavior are $57.2 \%$, while mothers who have poor clean healthy behavior are $42.8 \%$.

\subsection{UNIVARIATE ANALYSIS}

Table 1. Distribution of Respondents Based on Mother's Clean, Healthy Life, Knowledge, Attitude and Behavior

\begin{tabular}{lll}
\hline Criteria & Total & $\%$ \\
\hline Mothers Knowledge: & & \\
Good & 83 & 60,1 \\
Not Good & 55 & 39,9 \\
Mothers Action: & & \\
Positive & 70 & 50,7 \\
Negative & 68 & 49,3 \\
Mothers Clean Hygiene Behavior & & \\
Good & 79 & 57,2 \\
Not Good & 59 & 42,8 \\
\hline
\end{tabular}

Table 2. Distribution of Respondents by Incidence of Diarrhea in Toddlers

\begin{tabular}{ccc}
\hline Diarrhea & Frequency $(\mathbf{n})$ & Precentage (\%) \\
\hline Chronic & 73 & 52,9 \\
\hline Acute & 65 & 47,1 \\
\hline Total & 138 & 100 \\
\hline
\end{tabular}

Based on Table 2 above shows that the total incidence of diarrhea in toddlers is 138, with toddlers affected by chronic diarrhea as many as 73 (52.9\%), while toddlers affected by acute diarrhea as many as $65(47.1 \%)$.

\section{*Corresponding Author :}

Yarmaliza

Program Studi Ilmu Kesehatan Masyarakat

Universitas Teuku Umar, Indonesia

Email : yarmaliza@gmail.com 


\subsection{BIVARIATE ANALYSIS}

Tabel 3. Effect of Knowledge on the Incidence of Diarrhea in Toddlers

\begin{tabular}{|c|c|c|c|c|c|c|c|c|}
\hline \multirow{3}{*}{ Variable } & \multicolumn{4}{|c|}{ Diarrhea } & \multirow{2}{*}{\multicolumn{2}{|c|}{ Total }} & \multirow{3}{*}{$\mathbf{P}$} & \multirow{3}{*}{$\begin{array}{c}\text { RP } \\
\text { (Ci 95\%) }\end{array}$} \\
\hline & \multicolumn{2}{|c|}{ Chronic } & \multicolumn{2}{|c|}{ Acute } & & & & \\
\hline & $f$ & $\%$ & $f$ & $\%$ & $\mathbf{F}$ & $\%$ & & \\
\hline \multicolumn{9}{|c|}{ Knowledge } \\
\hline Good & 64 & 77,1 & 19 & 22,9 & 83 & 100 & \multirow[t]{2}{*}{0,000} & 0,27 \\
\hline Not Good & 9 & 16,4 & 46 & 83,6 & 55 & 100 & & $(0,18-0,41)$ \\
\hline \multicolumn{9}{|l|}{ Attitude } \\
\hline Positive & 53 & 75,5 & 17 & 24,3 & 70 & 100 & \multirow{2}{*}{0,000} & 2,9 \\
\hline Negative & 20 & 29,4 & 48 & 70,6 & 68 & 100 & & $(1,87-4,51)$ \\
\hline
\end{tabular}

Mothers Clean Healthy Behavior

\begin{tabular}{|c|c|c|c|c|c|c|c|c|}
\hline Good & 20 & 25,3 & 59 & 74,7 & 79 & 100 & & 7,3 \\
\hline Not Good & 53 & 89,8 & 6 & 10,2 & 59 & 100 & & $(3,40-15,84)$ \\
\hline
\end{tabular}

Based on Table. 3 it is known from 83 respondents who have good knowledge, 64 respondents $(77.1 \%)$ of whom had toddlers had chronic diarrhea, and as many as 19 respondents (22.9\%) whose toddlers had acute diarrhea. In particular, of the 55 respondents who had poor knowledge, 9 respondents (16.4\%) had chronic diarrhea, and 46 respondents $(83.6 \%)$ had acute diarrhea. Based on the chi square test results obtained value of Pvalue $=0,000$ and this is smaller than $\alpha=0.05$ (Pvalue $=0,000<\alpha=$ 0.05 ) so that there are described the influence of knowledge factors on the incidence of diarrhea in infants, and the results of RP 0.27 it can be concluded that knowledge has a smaller risk of the incidence of diarrhea in infants.

Based on Table. 3 it is known that of the 70 respondents who had positive attitudes as many as 53 respondents (75.5\%) whose toddlers experienced chronic diarrhea, and as many as 17 respondents $(24.3 \%)$ whose toddlers experienced acute diarrhea. Also seen from 68 respondents who had negative attitudes as many as 20 respondents (29.4\%) whose toddlers had chronic diarrhea, and as many as 48 respondents (70.6\%) whose toddlers experienced acute diarrhea. Chi square test results obtained value of Pvalue $=0,000$ and this is smaller than $\alpha=0.05$ (Pvalue $=0,000<\alpha=$ 0.05 ) so that there is an influence between attitudes towards diarrhea in infants, and the results of RP 2.9 can concluded that attitude has a risk of 2.9 times the incidence of diarrhea in infants.

Based on Table. 3 it is known that of the 79 respondents who did Clean and Healthy Life Behavior as many as 20 respondents (25.3\%) whose toddlers had chronic diarrhea, and as many as 59 respondents $(74.7 \%)$ whose toddlers experienced acute diarrhea. Furthermore, 59 respondents who did not have clean and healthy living behaviors were 53 respondents $(89.8 \%)$ of whom I had chronic diarrhea and 6 respondents (10.2\%) whose toddlers experienced acute diarrhea. Chi square test results obtained value of Pvalue $=0,000$ and this is smaller than $\alpha=0.05$ (Pvalue $=0,000<\alpha=0.05$ ) so that it is described there is an influence between clean heathy behavior factors on the incidence of diarrhea in infants, and the results of Rp. 7.3 can concluded that Clean and Healthy Behavior has a risk of 7.3 times the incidence of diarrhea in infants.

\section{*Corresponding Author :}

Yarmaliza

Program Studi Ilmu Kesehatan Masyarakat

Universitas Teuku Umar, Indonesia

Email : yarmaliza@gmail.com 


\subsection{MULTIVARIATE ANALYSIS}

From the results of the statistical test of the bivariate logistic regression model, the mother's attitude variable has a value of $p, 0.25$, with that value the attitude variable cannot be tested further in multivariate analysis to find out which variable most influences the incidence of diarrhea in infants. Knowledge and clean healthy behavior of mothers regarding the incidence of diarrhea in infants can be seen in Table. 4 Based on. Table 4. we can see the mother's knowledge from the results of the logistic regression test with $\mathrm{p}<0.05$ (95\% Cl: 3.645-252,379), this shows that there is a strong relationship between mother's knowledge of the incidence of diarrhea in infants. Likewise in the clean healthy behavior of the mother, from the table we can see that the value of $p<0.05(4,524-321,242)$ gives a meaning that there is a very strong relationship between clean healthy behavior of the mother against the incidence of diarrhea in infants.

Tabel. 4 Effect of Knowledge and Celan Healthy Behavior of mothers on the incidence of diarrhea in toddlers

\begin{tabular}{lllcl}
\hline Variable & Category & Nilai $\boldsymbol{p}$ & $\mathbf{9 5 \%}$ Cl & Exp (B) \\
\hline Mothers Knowledge & - Good & 0,001 & $3,645-252,379$ & 34,123 \\
& - Not Good & & & 36,201 \\
\hline $\begin{array}{l}\text { Mothers Clean } \\
\text { Healthy Behavior }\end{array}$ & - Good & 0,000 & $4,524-321,242$ & \\
\hline
\end{tabular}

\section{DISCUSSION}

\subsection{Mother's Knowledge}

Based on the chi square test results obtained value of Pvalue $=0,000$ and this is smaller than $\alpha=0.05$ (Pvalue $=0,000<\alpha=0.05$ ) so that there are described the influence of knowledge factors on the incidence of diarrhea in infants and have the results of RP 0.27 it can be concluded that knowledge has a smaller risk of the incidence of diarrhea in infants.

(Eralita., 2011), states that mothers who have an understanding / knowledge of the occurrence of diarrhea will be the basis for the formation of attitudes and behaviors with maternal tips in preventing and managing diarrhea in their toddlers so that they do not experience severe dehydration, while the lack of understanding of the mother will naturally experiencing difficulties in order to prevent further effects on diarrhea that does not get a complete treatment that is dehydration and further impact is the death of children under five. The same studies was also conducted by (Yarmaliza, 2017) that there is an influence between mother's knowledge on the incidence of diarrhea in toddlers. Furthermore Musihb and Gaduu (2015) also mentioned that the mother's knowledge of diarrhea prevention procedures would reduce the possibility of dehydration getting worse so as to enable the toddler to be dehydrated and cause death.

The same thing was expressed by Maharani (2013), in his research which showed that mother's knowledge influences health especially toddlers, if good mother's knowledge will affect mother's understanding, and vice versa, if mother's knowledge is not good then it will affect understanding mother. According to Tobin, et al., (2014) suggested that knowledge is a predisposing factor in someone's behavior, before someone adopts the behavior (new behavior), he must know in advance what the meaning or benefit of the behavior for himself. Furthermore, according to Mwambete et al., (2010), a mother will adopt a healthy lifestyle if she already knows what dangers and losses will occur if she does not do so.

\author{
*Corresponding Author : \\ Yarmaliza \\ Program Studi Ilmu Kesehatan Masyarakat \\ Universitas Teuku Umar, Indonesia \\ Email : yarmaliza@gmail.com
}


According to Notoatmodjo (2012), knowledge is the result of tofu and this happens after people have sensed an object, sensing here is vision, hearing, smell, taste and touch, most of human knowledge is obtained through the eyes and ears. The same study was also carried out by Evayanti (2014), who stated that maternal knowledge about poor environmental conditions was one of the factors increasing the incidence of diarrhea, due to the health status of an environment that included housing, sewage disposal, and clean water supply. The same thing was expressed by Ustun, at al ,. (2014) poor hygiene and sanitation can cause major environmental health problems because they can cause an outbreak of diarrheal disease and affect public health conditions.

Lindawati (2012), in her research also mentioned that the mother's knowledge about child hygiene and environmental hygiene plays an important role in children's physical and psychological growth and development. Poor child hygiene, will facilitate the occurrence of intestinal worms and diarrhea in children (Tambuwu, 2015). Therefore, sufficient education and knowledge must be possessed by the mother, so that the mother can know how to create a good and suitable environment for child growth and development, thereby increasing the sense of security for children (Tobin, et al., 2014).

\subsection{MOTHER'S ATTITUDE}

Based on the chi square test results obtained value of Pvalue $=0,000$ and this is smaller than $\alpha=0.05$ (Pvalue $=0,000<\alpha=0.05$ ) so that there are described the influence of attitude factors on the incidence of diarrhea in infants. Likewise from the results of statistical tests it can be seen that the results of Rp. 2.9 can be concluded that attitudes have a risk of 2.9 times the incidence of diarrhea in infants.

Based on a survey conducted by researchers, mothers who have toddlers with diarrhea show poor environmental hygiene. Furthermore (Tobin, Isah, \& Asogun, 20 14), improper disposal of household wastewater also contrib- utes to environmental sanitation, because diarrhea is an environmental-based disease. If environmental factors are unhealthy and polluted, then the germs that cause diarrhea accumulate with unhealthy human behavior that will lead to the incidence of toddler diarrhea that is transmitted through food and drink (Ansari et al., 2012)

The above is supported by the opinion of (Agus, A.M., et al, 2014), which states that the mother's attitude greatly determines one's health, in this case the attitude of mothers who have toddlers with diarrhea. Attitude is a belief or opinion towards people or objects and ideas. Therefore, if the mother's attitude towards health, especially about diarrhea in infants is good, it will affect the health of the toddler (Yarmaliza, et al,. 2020).

From the results of (Evayanti, N.K.E., et al, 2014), it also shows that the incidence of diarrhea is closely related to the mother's attitude, if the mother's attitude is good it will affect the health of children under five, one example of a good mother's attitude is as revealed by (Handita, T., and Sungkar, 2015), namely the level of trust mother towards washing hands before eating. The results of this study are consistent with research conducted by (Hannif., Nenny, S, and Kuscithawati, 2011), which states that there is a significant relationship between maternal attitudes and the incidence of diarrhea in infants.

Attitude is a predisposing factor in a person's behavior revealing the existence of a relationship and attitudes conformity with one's behavior, according to Lawrence Green's theory (Notoatmojo, 2012), that a person's behavior is influenced by knowledge, attitudes, beliefs, and others.

(Notoatmojo, 2012) expressing attitude is a view or feeling accompanied by a tendency to act in accordance with the attitude towards a particular object, then a negative mother's attitude toward healthy living behavior is likely to cause diarrhea pain. The formation of attitudes is influenced by personal experience, culture, other people who are considered important, the mass media, institutions or educational institutions themselves and religious institutions, as well as

\section{*Corresponding Author : \\ Yarmaliza \\ Program Studi Ilmu Kesehatan Masyarakat \\ Universitas Teuku Umar, Indonesia \\ Email : yarmaliza@gmail.com}


emotional factors in individuals.

(Yarmaliza, at al, 2016), revealed to increase the positive attitude of mothers towards clean and healthy living behaviors, through approaches to community leaders and religious organizations (pengajian, majelis taklim). This approach to community leaders needs to be done because they are role models of the community and all their decisions are a way for a smooth disease eradication program (P2) diarrhea (Njuguna \& Muruka, 2011). It is hoped that after this approach is made, it will be easier for the community to understand the aims and objectives of counseling, and mothers become aware and positive about healthy living behavior both in washing hands with soap and in maintaining healthy water and toilet facilities (Rosidi, et al., 2010).

\subsection{MOTHER'S CLEAN HEALTHY BEHAVIOR}

Based on the chi square test results obtained value of Pvalue $=0,000$ and this is smaller than $\alpha=0.05$ (Pvalue $=0,000<\alpha=0.05$ ) so that there are described the influence of the Clean and Healthy Behavior factors on the incidence of diarrhea in infants, with the results IDR 7.3 can be concluded that Clean and Healthy Life Behavior has a risk of 7.3 times the incidence of diarrhea in infants.

The survey results are known, mothers who have toddlers with diarrhea show poor household environmental hygiene. According to (Fatrisia, et al, 2016), mother's actions will affect the health of children under five, especially related to environmental health, such as disposing of trash in its place and keeping the environment in order to remain hygienic, so that it can break the chain of disease transmission through dirty environments and clean and healthy living behaviors so that it is not easy contracting a disease.

A similar statement was expressed by (Qureshi, at al, 2010), that the mother's actions are closely related to the incidence of diarrhea in infants, mother's actions such as closing food that is ready to eat, washing hands before eating will affect health. From the research results of (Najamuddin, 2014) it also shows that the incidence of diarrhea is closely related to the actions of the mother, if the mother's actions are healthy or good, it will affect the health of infants, one example of good mother's actions is as revealed by (Agriati, Y.M., G.D. Kandou., 2013) namely the mother's actions to clean the home environment, if the home environment is maintained from various kinds of germs, it will reduce the risk of various diseases, for example the incidence of diarrhea in infants.

The results of this study are consistent with research conducted by (Irawan, 2013), which states that there is a relationship between maternal actions and the incidence of diarrhea in infants. Ztated that environmental cleanliness is one of the most important things to be maintained, this has a strong influence on the daily actions of mothers who reflect health (Yarmaliza, 2018). The results of this study are in accordance with the theory put forward by the (Ministry of Health, 2010), habits related to personal hygiene that are important in transmitting diarrhea is washing hands.

According to (Yarmaliza, 2020), washing hands with soap, especially after defecating, after disposing of children's feces, before preparing food, has an impact on diarrhea. Preventive measures so that germ attacks can be avoided should be done, including by washing hands with soap before giving food to infants and children, avoiding snacks for children and toddlers, heating water to be drunk, avoiding food that is stale or moldy and parasitic contamination (Tambuwun et al., 2015). Therefore hand hygiene by washing hands needs to be given high priority, although this is often overlooked (Ministry of Health, 2010), washing with soap as a cleaner, rubbing, and rinsing with running water will wash away dirt particles that contain lots of microorganisms. The habit of washing hands with soap, apparently can reduce the incidence of diarrhea by $50 \%$ or the same as saving about 1 million children in the world from the disease each year (Ministry of Health, 2010). Furthermore (Njuguna \& Muruka, 2011), said that diarrhea is a contagious disease, especially in the transition season, usually in the

\section{*Corresponding Author : \\ Yarmaliza \\ Program Studi Ilmu Kesehatan Masyarakat \\ Universitas Teuku Umar, Indonesia \\ Email : yarmaliza@gmail.com}


transition season there are many flies (animals carrying bacteria). These flies perched on food, so food is not hygienic and can cause diarrhea (Almazan, 2014) A mother who has good knowledge, of course, the mother first knows what diarrhea is, the cause of diarrhea, symptoms, ways of transmission and the importance of washing hands with soap, the dangers that will arise if they do not behave cleanly for themselves or their families (Dewi, 2014)

According to (Notoadmojo, 2012) it states that after a person knows a stimulus or object, it then gives rise to an inner response in the form of the subject's attitude towards the known object. In this case after the mother knows the purpose and benefits of healthy living behavior for herself or her family and the dangers that will occur if the behavior does not live healthy, then the mother will assess or respond to the behavior, for example, she is expected to carry out handwashing with soap before and after eating or after defecating, and maintaining clean water and toilet facilities as an effort to prevent diarrhea.

(Hajar \& Darmawan, 2013), stated that the process of forming behavior also needs to be

\section{CONCLUSION}

There is an influence between knowledge, attitudes and behaviors of healthy and clean liv- supported by the health center for example, by increasing the frequency of environmental sanitation inspections by environmental health workers to find out whether mothers who have been given counseling understand and are aware and have behaved in healthy lives that can be seen from the condition of its clean water facilities and latrines. So if the mother is able to behave in a healthy life and even implant it in all family members, it is expected that diarrheal disease can decrease (Yarmaliza, et al, 2020). (Dini, F., Mahmud, R, dan Rasyid, 2015) revealed that the habit of disposing garbage in the wrong place is also a risk factor for the emergence of various disease vector. (Rauf et al., 2013), stated that other risk factors that cause diarrhea for toddlers are garbage bins that are used with a weak and leaky construction such as plastic containers and plastic bags and in some trash bin conditions there are vectors such as insects that can cause diarrhea in toddler. Good waste management is very important to prevent transmission of disease by providing trash bins, rubbish must be collected every day and disposed of in temporary shelters (Yarmaliza, at al,. 2016).

ing of mothers on the incidence of diarrhea in infants. Mother's knowledge provides a stronger influence on the incidence of diarrhea in infants.

nents and the writer's team who contributed to the research until the completion of this article. who have supported this research so that it can be published, and also thank you to all compo-

\title{
REFERENCES
}

[1] Agriati, Y.M., G.D. Kandou., dan F. R. R. M. (2013). Gambaran perilaku ibu rumah tangga tentang penanggulangan diare. E Biomedik, 1(1), 17-20.

[2] Agus, A.M., Avin M.K., Gisantia B., E. P. S. (2014). Analisis Kondisi Hygiene Sanitasi Makanan dengan Kejadian Diare Pada Balita. Jurnal Ilmu Berbagi. Seri IImu Kesehatan Dan Lingkungan, 2, 82-91.

\author{
*Corresponding Author : \\ Yarmaliza \\ Program Studi Ilmu Kesehatan Masyarakat \\ Universitas Teuku Umar, Indonesia \\ Email : yarmaliza@gmail.com
}


[3] Almazan, J. U. (2014). Participatory hygiene and sanitation transformation (PHAST) in a remote and isolated community. Int.J. InterdisciplParticipatory Hygiene and Sanitation Transformation (PHAST) in a Remote and Isolated Community Res. Innov., 2(3), 22-29.

[4] Ansari, S., Sherchand, J. B., Parajuli, K., Paudyal, B. M., Adhikari, R. P., Shrestha, S., Pokhrel, B. M. (2012). Pattern of Acute Parasitic Diarrhea in Children Under Five Years of Age in Kathmandu, Nepal. Open Journal of Medical Microbiology, 02(03), 95-100. https://doi.org/10.4236/ojmm.2012.23014

[5] Community Health Center Teunom. (2016).

[6] Dewi, A. M. (2014). (2014). Hubungan tingkat pendidikan, pengetahuan dan tindakan ibu tentang pencegahan diare dengan kejadian diare pada balita. Tesis. Program Pascasarjana. Universitas Indonesia.

[7] Dini, F., Mahmud, R, dan Rasyid, R. (2015). $\mathrm{H}$. faktor lingkungan dengan kejadian diare balita. J. K. A. 4 (2): 453-461. (2015). Hubungan faktor lingkungan dengan kejadian diare balita. Jurnal Kesehatan Andalas, 4(2), 453-461.

[8] Eralita. (2011). Corelation of environmental sanitation, womens knowledgeand behavior to the acute diarrhea in underfives children ofpahandut subdistrict. Tesis. Program Pascasarjana. Universitas Gajah Mada.

[9] Evayanti, N.K.E., Purna. I.N, dan Aryana, I. K. (2014). Faktor-faktor yang berhubungan dengan kejadian diare pada balita. Jurnal Kesehatan Lingkungan. Jurnal Kesehatan Lingkungan, 4(2), 134-139.

[10] Fatrisia, R., Redjeki, E. S., \& Gayatri, R. W. (2016). Faktor Yang Berhubungan Dengan Kejadian diare pada masyarakat peternak sapi perah. 1-8. Retrieved from journal.um.ac.id/index.php/preventia/article/dow nload/9981/4716\%0A

[11] Hajar, I., \& Darmawan, S. (2013). Diare Pada Anak Usia 1-3 Tahun. 2(2), 1-10. Retrieved from http://ejournal.stikesnh.ac.id/index.php/jikd/ar ticle/view/409

[12] Handita, T., and Sungkar, S. (2015). The Trend of Diarrhea in Kodi and Kodi Utara Subdistricts. Journal EJKI, 2(3), 12-20.

\section{*Corresponding Author :}

Yarmaliza

Program Studi Ilmu Kesehatan Masyarakat

Universitas Teuku Umar, Indonesia

Email : yarmaliza@gmail.com
[13] Hannif., Nenny, S, dan Kuscithawati, S. (2011). Faktor Risiko Diare Akut Pada Balita. Berita Kedokteran Masyarakat., 27(1), 10-17.

[14] Irawan, A. Y. (2013). Hubungan Antara Aspek Kesehatan Lingkungan Dalam Phbs Rumah Tangga Dengan Kejadian Penyakit Diare Di Kecamatan Karangreja Tahun 2012. Unnes Journal of Public Health., 2(4). https://doi.org/10.15294/ujph.v2i4.3058

[15] McFarland, L., Elmer, G., \& McFarland, M. (2006). Meta-analysis of probiotics for the prevention and treatment of acute pediatric diarrhea. International Journal of Probiotics and Prebiotics, 1(1), 63.

[16] Ministry of Health. (2010). Profil Kesehatan Indonesia.

[17] Ministry of Health Republic of indonesia. (2015). Laporan Kesehatan Indonesia.

[18] Najamuddin, A. (2014). Hubungan antara pengetahuan dan lingkungan dengan kejadian diare akut pada anak di kelurahan pabbundukang kecamatan pangkajene kabupaten pangkep. Jurnal Kesehatan, VII(2), 346352.

[19] Njuguna, J., \& Muruka, C. (2011). Diarrhoea and malnutrition among children in a Kenyan District: a correlational study. Journal of Rural and Tropical Public Health, 10, 35-38. Retrieved from https://auth.lib.unc.edu/ezproxy_auth.php?url =http://search.ebscohost.com/login.aspx?dir ect=true $\& \mathrm{db}=\mathrm{Ihh} \& A \mathrm{~N}=20123050620 \&$ site $=e$ host-

live\&scope=site;\%5Cnhttp://www.cabi.org/ca bdi-

rect/showpdf.aspx?PAN=20123050620;\%5C nhttp://www.jcu.edu.au/jrtph/vol/JRTPH_Vol1

[20] Notoadmojo, S. (2012). P. kesehatan ilmu perilaku. R. cipta. J. Pendidikan kesehatan ilmu perilaku. Rineka cipta. Jakarta.

[21] Notoatmojo, S. (2012). Promosi Kesehatan dan IImu Perilaku. Jakarta: Rineka Cipta.

[22] Purbasari, E. (2009). Tingkat pengetahuan, sikap, dan perilaku ibu dalam penanganan awal diare pada balita, Program Sarjana Kedokteran, Universitas Islam Negeri Syarief Hidayatullah Jakarta. 
[23] Qureshi, A. A., Omer, S., Eswar Kumar, K., \& Bhajipale, N. S. (2010). Probiotics in diarrhea: Myths and facts. International Journal of Pharmacy and Pharmaceutical Sciences, 2(SUPPL. 3), 23-28.

[24] Rauf, H., Adhiwijaya, A., Aminah, S., Makassar, N. H., Makassar, N. H., \& Makassar, N. H. (2013). Hubungan Pengetahaun, Sikap dan Perilaku Ibu Terhadap Derajat Kejadian Diare Pada Balita. 2, 44-52.

[25] Tambuwun, F., Ismanto, A. Y., Silolonga, W., Studi, P., Keperawatan, I., Kedokteran, F., \& Ratulangi, U. S. (2015). Hubungan Sanitasi Lingkungan Dengan Kejadian Diare Pada Anak Usia Sekolah Di Wilayah Kerja Puskesmas Bahu Manado. Jurnal Keperawatan, 3(2).

[26] Yarmaliza, Y, Sugito, S, Ferasyi, TR, Nurliana, N, Razali, R. (2016). Effects of Mothers' Attitude as Breeders and Distance of Stockyard toward Diarrhea Incidence among Toddlers. Jurnal Kesmas Nas. : National Public Health Journal 10 (3), 140-144

[27] Yarmaliza, Y, Farisni, TN, Fitriani, F.(2020). Epidemiological evaluation: analysis of mother's characteristics, against the incidence of diarrhea in toddlers. International Journal of Medical Science and Clinical Research 1 (4), 15-19

[28] Yarmaliza, Y, Fitriani, F, Farisni, TN, Eki, Lili N. (2020) Identifikasi Karakteristik Ibu Terhadap Faktor Resiko Kejadian Diare Pada Balita. Jurnal Maternitas Kebidanan, Vol 5, No. 2

[29] Yarmaliza, Y, Farisni, TN, Fitriani, F, D.Susanna, Reynaldi, F, Zakiyuddin, Z. SA, Safrizal. (2020). Indian Journal of Public Health Research \& Development. Vol. 11, No. 04. 947-953

[30] Tobin, E., Isah, E., \& Asogun, D. (2014). Care giver's knowledge about childhood diarrheal management in a rural community in South-South Nigeria. International Journal of Community Research, 3(4), 93-99.

[31] Yarmaliza. (2017). Analisis Karakteristik Ibu terhadap Kejadian Diare pada Balita. Prosiding Seminar Nasional IKAKESMADA "Peran Tenaga Kesehatan dalam Pelaksanaan SDGs."

\section{*Corresponding Author :}

Yarmaliza

Program Studi Ilmu Kesehatan Masyarakat

Universitas Teuku Umar, Indonesia

Email : yarmaliza@gmail.com
[32] Yarmaliza. (2018). The Effects of Improper Household Waste Management by Mothers on the Genesis of Diarrhea in Toddlers. Journal of International Dental and Medical Research, 11(3), 1053-1057. 